\title{
Investigation of pipes and sprinklers scaling at the golf course turf irrigated by treated wastewater of Mzar plant in Agadir-Morocco
}

\author{
Said Mohareb, Ilham Karmal, Abdallah Hadfi, Said Ben-aazza, M'barek Belattar, Naima Hafid, \\ Mohamed El housse and Ali Driouiche
}

Team "Materials and Physical Chemistry of Water", Laboratory of Process Engineering, Faculty of Sciences, Ibn Zohr University, Agadir, Morocco

\begin{abstract}
In Agadir city, the reuse of treated wastewater for irrigation of green spaces has faced the problem of scaling of the pipes of these waters. This research paper aims at studying the phenomenon of scaling caused by the treated wastewater from the Mzar sewage treatment plant in the city of Agadir in south-west of Morocco. These waters are used in the irrigation of golf turf "Ocean". The formation of solid deposits in the irrigation systems has decreased their lifetime, and consequently, a loss of load and performance is occurring. Thus, the sprinklers used in golf turf irrigation are plugged in the first weeks of the beginning of their operation. The wastewater used for the irrigation of the golf was analyzed at various points using physicochemical measurements: in the golf entry, at the tarpaulin and the exit of the sprinklers. The samples of treated wastewater and obtained scale were studied. The characterization of the scale samples formed in the passageways of the treated wastewaters has been performed by X-ray fluorescence spectrometry, X-ray diffraction, thermogravimetric analysis, differential thermal analysis and scanning electron microscopy. The results of the physicochemical analysis of the waters show that they are full of bicarbonates $(653 \mathrm{mg} / \mathrm{L})$, chloride $(478 \mathrm{mg} / \mathrm{L})$, nitrate $(412 \mathrm{mg} / \mathrm{L})$, sodium $(425 \mathrm{mg} / \mathrm{L})$ and in calcium $(199$ $\mathrm{mg} / \mathrm{L})$. Their $\mathrm{pH}$ is slightly alkaline. The analysis of the scale reveals that it is rich in calcium and phosphorus. It is formed of calcium carbonate $\left(\mathrm{CaCO}_{3}\right)$, silica $\left(\mathrm{SiO}_{2}\right)$, calcium silicate $\left(\mathrm{Ca}_{2} \mathrm{SiO}_{4}\right)$, hydroxylapatite $\left(\mathrm{Ca}_{10} \mathrm{P}_{6} \mathrm{O}_{26} \mathrm{H}_{2}\right)$, calcium carbonate-apatite $\left(\mathrm{Ca}_{10}\left(\mathrm{PO}_{4}\right) 6 \mathrm{CO}_{3}\right)$ and silicate calcium and magnesium $\left(\mathrm{Ca}_{5} \mathrm{MgSi}_{3} \mathrm{O}_{12}\right)$.
\end{abstract}

Keywords: Scaling water; wastewater; scale; irrigation; Agadir.

\section{Introduction}

The region of Souss Massa in the south-west of Morocco is known for its semi-arid climate and its minimal water resources. In order to mitigate this water deficit, the development master plan for this region recommends resorting to unconventional resources. The reuse of treated wastewater to reduce this water deficit is now inevitable. Infrastructures have been made to serve the golf and green spaces of the city of Agadir by treated wastewater from Mzar station in the city. The average flow of treated wastewater is $30000 \mathrm{~m}^{3} / \mathrm{d}^{1-2}$. Nevertheless, this reuse of treated water has encountered the problem of scaling of water pipelines. This phenomenon has created technical economic and environmental problems.

This study aims, on the one hand, to examine the physical and chemical quality of the treated wastewater used for irrigation of golf turf. On the other hand, it aims identifying and characterizing the scale deposits assembled at the level of the pipes and sprinklers of the "Ocean" golf.

\section{Materials and methods}

\subsection{Site of the study and sampling}

The sewage treatment plant of wastewaters Mzar is located at approximately $4 \mathrm{~km}$ in the south of Agadir city on the left coast of Oued Souss on the coastal dunes of Mzar. Its western limit is about $1500 \mathrm{~m}$ from the sea.

The "ocean" golf, which was opened in January 2010, is located at $11 \mathrm{~km}$ from the city center of Agadir in the forest of Bensergao (Figure 1). Its total area is 100 hectares, of which 75 hectares are grassed. It has a storage tank of treated wastewater $15.000 \mathrm{~m}^{3}$ of capacity and $1.5 \mathrm{~m}$ of the depth off. The flow of daily watering rate ranges from 3000 to $4000 \mathrm{~m}^{3}$. 


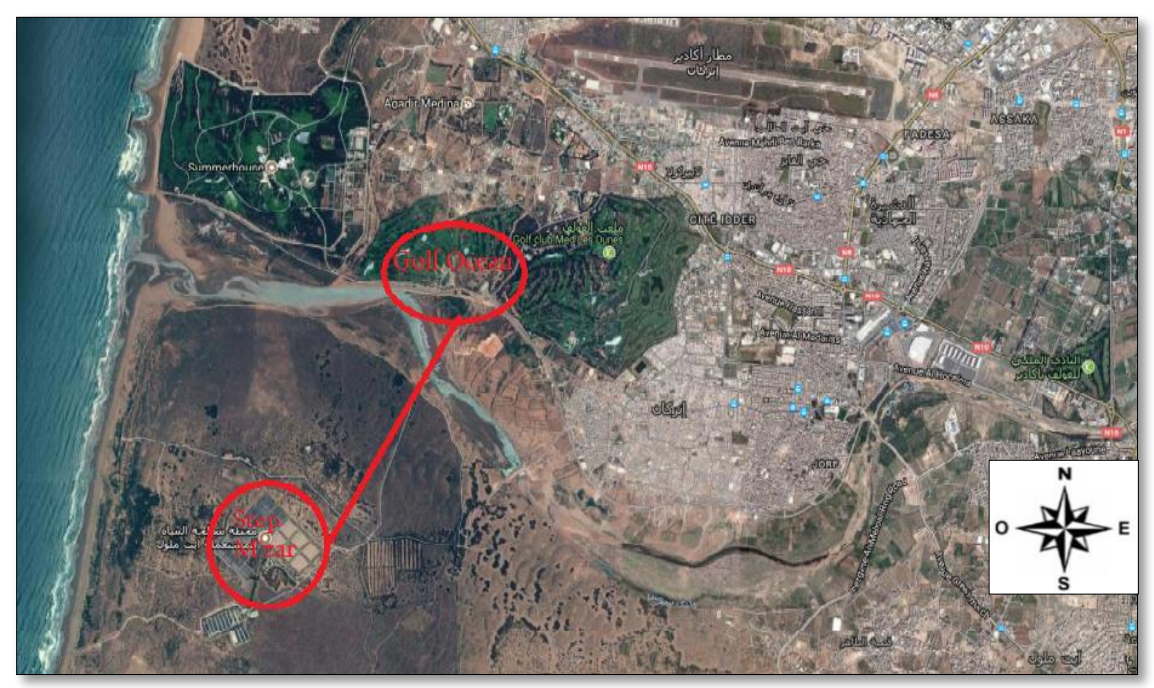

Figure 1. Location of the Mzar's sewage treatment plant and the "Ocean" golf

The studied scale was collected inside the golf at three different points. Figure 2 shows a sprinkler clogged

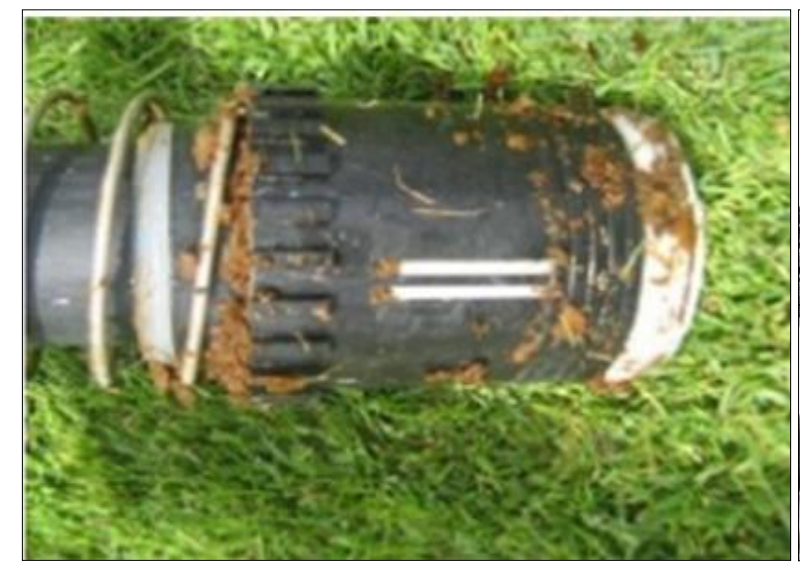

Figure 2. Sprinkler clogged by the scale

\subsection{Methods of analysis}

\subsubsection{Physicochemical analyzes}

Calcium $\left(\mathrm{Ca}^{2+}\right)$ and magnesium $\left(\mathrm{Mg}^{2+}\right)$ ions were determined by the atomic absorption method, while sodium $\left(\mathrm{Na}^{+}\right)$and potassium $\left(\mathrm{K}^{+}\right)$ions by flame spectrophotometry, chloride $\left(\mathrm{Cl}^{-}\right)$by Mohr method, sulfates $\left(\mathrm{SO}_{4}{ }^{2-}\right)$ by gravimetry, nitrates $\left(\mathrm{NO}_{3}{ }^{-}\right)$by visible spectrophotometry and bicarbonate by volumetry.

\subsubsection{X-ray Fluorescence Spectrometry Analysis} $\mathrm{X}$-rays are electromagnetic radiation ranging approximately between 0.1 and $50 \AA$. They are emitted by the bombardment of the surface of a solid by cathode rays. The scale was analyzed using XRF spectrometer Axios. The applied voltage is $60 \mathrm{kV}$ with a current intensity of $125 \mathrm{~mA}$ and $4000 \mathrm{~W}$ power.

\subsubsection{X-ray diffraction analysis}

The use of X-ray diffraction (XRD) spectroscopy is an essential step in accurately identifying the scale structure formed during the scaling process. The up by scale and Figure 3 shows the scale taken from the sprinkler.

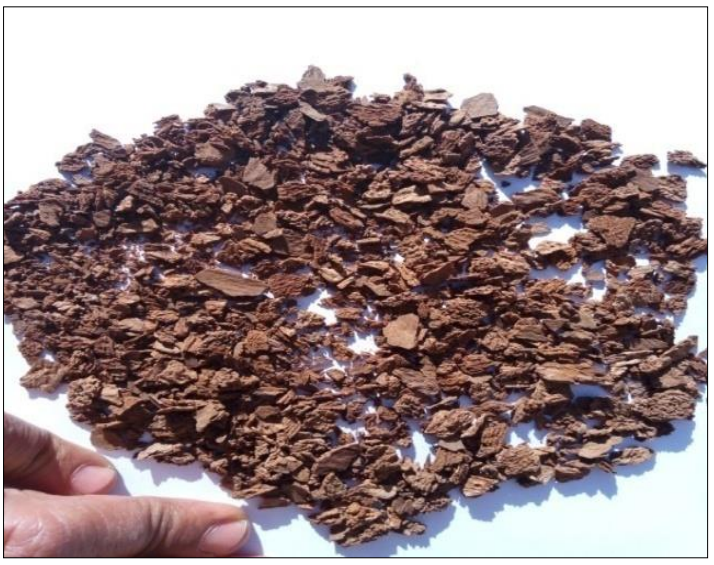

Figure 3. Golf Sprinkler scale

diffractometer used for these measurements is a goniometer with direct optical encoding connected to a computer and using a copper anticathode $\mathrm{K} \alpha$ $(\lambda=1.5406 \AA)$, with an absolute angular accuracy of 0.0025 and a reproducibility lower than 0.0001 degrees. The Scan is adopted with a step of $0.06682^{\circ}$.

\subsubsection{Differential thermal and gravimetric} analysis

Differential thermal analysis is a technique that measures the temperature difference between a sample and a reference according to time and / or temperature. Thermogravimetric analysis is a technique that measures the mass variation of a sample when it is subjected to temperature variation programming, under a controlled atmosphere. The thermal and gravimetric analysis of the scale was carried out by a thermogravimetric analyzer (TGA) apparatus combined with differential thermal analysis (DTA) of the type Shimadzu DTG- 60, under air with $10^{\circ} \mathrm{C} / \mathrm{mn}$, from $0^{\circ} \mathrm{C}$ to $1100^{\circ} \mathrm{C}$. The flow rate used is $10 \mathrm{~mL} / \mathrm{min}$. 


\subsubsection{Scanning electron microscopy analysis} Scanning electron microscopy (SEM) is used to gain visual mastery of the objects: the morphology of the grain boundaries and the porosity. It also allows highlighting the textural state of a powder or a material. The scale samples were dehydrated, treated and then placed on the slide. The micrographs of the scale are obtained by scanning electron microscope FEI Quanta 200 equipped with an EDX probe. The surface microanalysis is carried out with a resolution of $3.5 \mathrm{~nm}$ and optical magnification of 20-106 times.

\section{Results and discussion}

\subsection{Physicochemical analysis of treated} wastewater

The physicochemical parameters of the wastewater related to the scaling phenomenon were determined by taken water samples at three points: the golf entrance, the tarpaulin and from the sprinklers ${ }^{3}$. The obtained results are summarized in Table 1

Table 1. Physicochemical parameters of treated wastewater

\begin{tabular}{|c|c|c|c|c|}
\hline & Golf entrance & Tarpaulin & sprinkler & Moroccan norms \\
\hline $\mathbf{T}\left({ }^{\circ} \mathbf{C}\right)$ & 27.90 & 27.90 & 27.50 & 35.00 \\
\hline pH & 7.80 & 7.80 & 8.30 & $6.50-8.50$ \\
\hline $\mathrm{EC} \mathrm{(mS/cm)}$ & 2.82 & 2.86 & 2.90 & 12.00 \\
\hline $\mathrm{Ca}^{+}(\mathrm{mg} / \mathrm{l})$ & 199.00 & 196.00 & 201.00 & - \\
\hline $\mathrm{Mg}^{2+}(\mathrm{mg} / \mathrm{l})$ & 55.10 & 49.30 & 51.00 & - \\
\hline $\mathrm{K}^{+}(\mathrm{mg} / \mathrm{l})$ & 36.00 & 38.00 & 37.00 & - \\
\hline $\mathrm{Na}^{+}(\mathbf{m g} / \mathbf{l})$ & 414.00 & 431.00 & 430.00 & 69.00 \\
\hline $\mathrm{HCO}_{3}^{-}(\mathrm{mg} / \mathrm{l})$ & 635.00 & 659.00 & 665.00 & 518.00 \\
\hline $\mathrm{PO}_{3}^{-}(\mathrm{mg} / \mathrm{l})$ & 5.70 & 6.10 & 4.60 & \\
\hline $\mathrm{SO}_{4}{ }^{2-}(\mathrm{mg} / \mathrm{l})$ & 216.00 & 235.00 & 220.00 & 250.00 \\
\hline $\mathrm{NO}_{3}^{-}(\mathrm{mg} / \mathrm{l})$ & 428.00 & 402.00 & 405.00 & 30.00 \\
\hline $\mathrm{Cl}^{-}(\mathrm{mg} / \mathrm{l})$ & 458.00 & 484.00 & 493.00 & 105.00 \\
\hline
\end{tabular}

According to these results, treated wastewaters are slightly rich in alkaline $\mathrm{pH}$ of 8.3 at the level of the sprinkler. These waters have high contents of bicarbonate ions $\mathrm{HCO}_{3}{ }^{-}$, sodium $\mathrm{Na}^{+}$, nitrate $\mathrm{NO}_{3}{ }^{-}$, chloride $\mathrm{Cl}^{-}$and sulphate $\mathrm{SO}_{4}{ }^{2-}$. These contents widely exceed the values fixed by the Moroccan norms relating to the reuse of wastewaters for the irrigation of the public green spaces ${ }^{4-6}$.

The water used to irrigate golf turf "Ocean" has a slight amount of alkaline $\mathrm{pH}$, which has the effect of promoting the formation of scale ${ }^{7-9}$. The average value of the electrical conductivity highlights strong mineralization of these waters. Similar results were obtained on the treated waters of Mzar station ${ }^{10}$. Inside the Golf, a slight variation of the $\mathrm{pH}$ and the contents of calcium, bicarbonate, sulphate and chloride were noticed.

The treated water thus presents favorable conditions for the formation of chemical deposits in their passageways. All the sprinklers of the Golf are thus clogged up in the first weeks of the beginning of their operation. To overcome this problem, filters were installed upstream and downstream of the pipes. Few hours after this operation, filters are clogged and must be disassembled for cleaning.

\subsection{Chemical analysis of scale}

The results of the chemical analysis of the scale taken at the entrance of the golf course inside the tarpaulin and at the level of the sprinklers are collected in Table 2.

The chemical analysis of the studied scale reveals that the rates of dry matter and organic matter vary slightly from one point to another. They range from $76 \%$ to $78 \%$ and from $3.15 \%$ to $3.75 \%$ respectively. At the three sampling points, the $\mathrm{pH}$ is alkaline, and the electrical conductivity has higher values.

The chemical compositions of scales collected at the entrance to the golf course, inside the tarpaulin and at the watering sprinklers are relatively similar. The major oxides in these scales are $\mathrm{CaO}(35 \%)$ and $\mathrm{P}_{2} \mathrm{O}_{5}$ $(18 \%)$. These samples are completely and rapidly dissolved in the acid medium. Other elements and other oxides are present but with very low contents compared to the content of $\mathrm{CaO}$ and $\mathrm{P}_{2} \mathrm{O}_{5}$. Their iron contents are respectively $0.26 \%, 0.24 \%$ and $0.038 \%$.

Table 2. Chemical properties of scale taken at different points of the "Ocean" Golf Course

\begin{tabular}{|c|c|c|c|}
\hline & Golf entrance & Inside the tarpaulin & Sprinklers \\
\hline Dry matter (\%) & 78.00 & 78.32 & 76.00 \\
\hline Humidity (\%) & 22.00 & 21.68 & 24.00 \\
\hline Organicmatter (\%) & 3.75 & 3.20 & 3.15 \\
\hline EC ( $\mathbf{\mu S} / \mathbf{c m})$ & 7.95 & 7.52 & 8.20 \\
\hline $\mathbf{p H}$ & 9.32 & 9.29 & 9.40 \\
\hline $\mathbf{N}(\mathbf{\%})$ & 0.47 & 0.56 & 0.50 \\
\hline
\end{tabular}




\begin{tabular}{|c|c|c|c|}
\hline $\mathrm{P}_{2} \mathrm{O}_{5}(\%)$ & 17.92 & 19.27 & 16.95 \\
\hline $\mathrm{Cl}^{-}(\%)$ & 0.34 & 0.31 & 0.37 \\
\hline $\mathrm{K}_{2} \mathrm{O}(\%)$ & 0.02 & 0.02 & 0.02 \\
\hline $\operatorname{MgO}(\%)$ & 1.10 & 1.03 & 0.93 \\
\hline $\mathrm{CaO}(\%)$ & 31.83 & 34.07 & 38.92 \\
\hline $\mathrm{Na}_{2} \mathrm{O}(\%)$ & 0.27 & 0.23 & 0.32 \\
\hline Fe $(\%)$ & 0.26 & 0.24 & 0.04 \\
\hline $\mathrm{Cu}(\mathrm{mg} / \mathrm{Kg})$ & 206.00 & 44.00 & 31.00 \\
\hline Mn (mg/Kg) & 470.00 & 395.00 & 278.16 \\
\hline Zn (mg/Kg) & 280.00 & 88.00 & 76.38 \\
\hline
\end{tabular}

\subsection{X-ray fluorescence analysis}

The product collected at the sprinkler is moist and reddish. It was dried in an oven at $105^{\circ} \mathrm{C}$ for 24 hours and then ground to obtain a fine and homogeneous powder. This drying gave a mass loss of $24 \%$. The product color changed and became light brown.
The qualitative analysis by X-ray fluorescence spectrometry made it possible to identify the chemical elements in the scale sample. Calcium and phosphorus are the significant elements in the scale. They have two intense peaks (Figure 4).
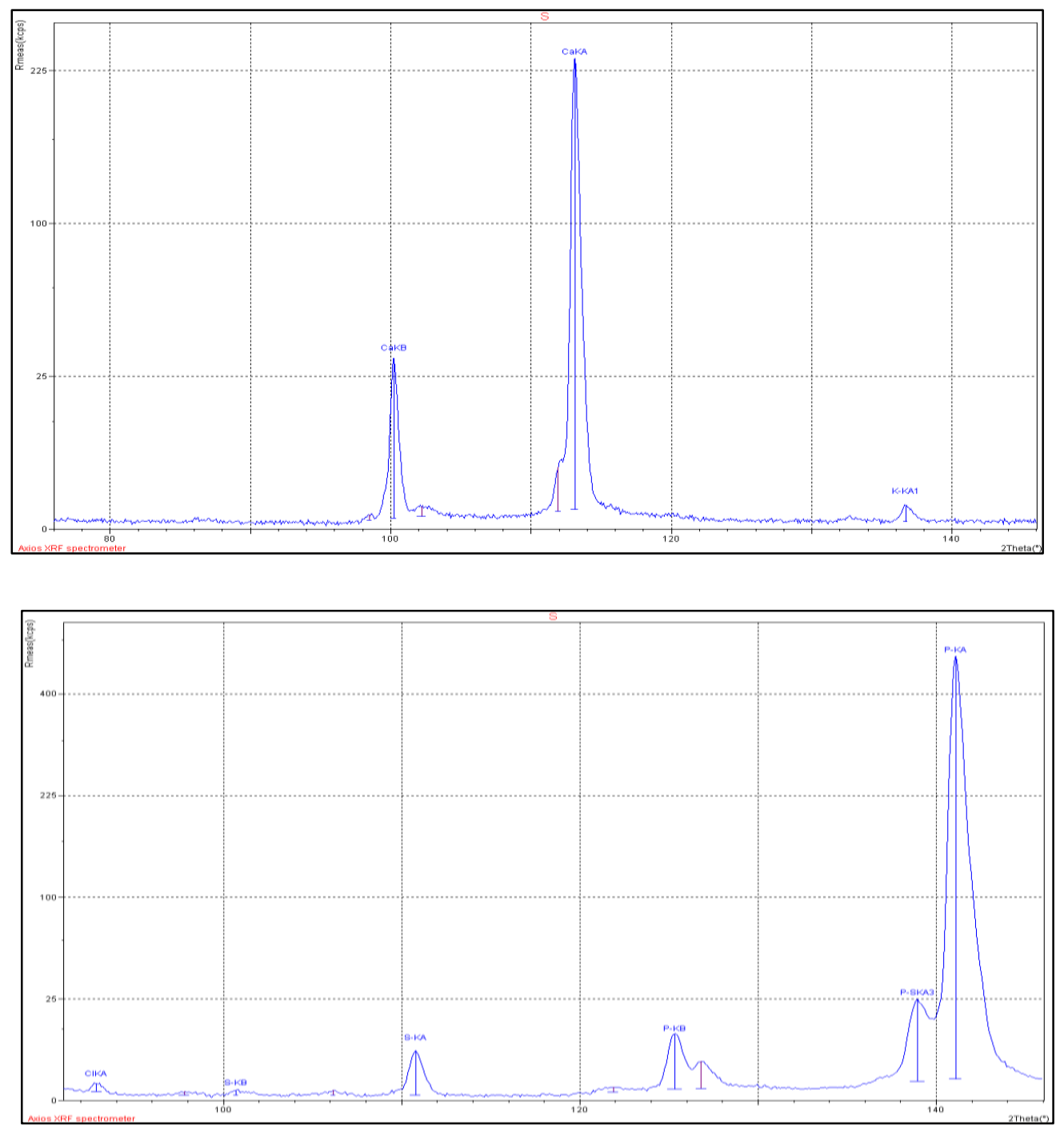

Figure 4. X-ray fluorescence spectrum of deposited scale

They are followed by the magnesium and silicon elements. Other elements such as oxygen, carbon, sulfur, iron and sodium are also present with peaks of very low intensities. The quantitative analysis (XRF) of scale are shown in Table 3. 
Table 3. Elemental composition of deposited scale

\begin{tabular}{|c|c|c|c|c|c|c|}
\hline & Ca & P & Mg & Si & Na & Fe \\
\hline \% Mass & 71.92 & 25.85 & 0.89 & 0.73 & 0.24 & 0.38 \\
\hline \% Atomic & 66.25 & 30.82 & 1.35 & 0.96 & 0.38 & 0.25 \\
\hline
\end{tabular}

The scale contains $72 \%$ of calcium, $26 \%$ of phosphorus incomplete weight. The other elements $\mathrm{Mg}, \mathrm{Si}, \mathrm{Na}$ and $\mathrm{Fe}$ are present with mass percentages lower than 1 . In the calcined product, calcium oxide $(\mathrm{CaO})$ is the major compound with a level of $38.92 \%$ followed by phosphorus pentoxide $\left(\mathrm{P}_{2} \mathrm{O}_{5}\right)$ with a percentage of $16.95 \%$ in weight. Other trace oxides have been detected such as magnesium oxide $\mathrm{MgO}$

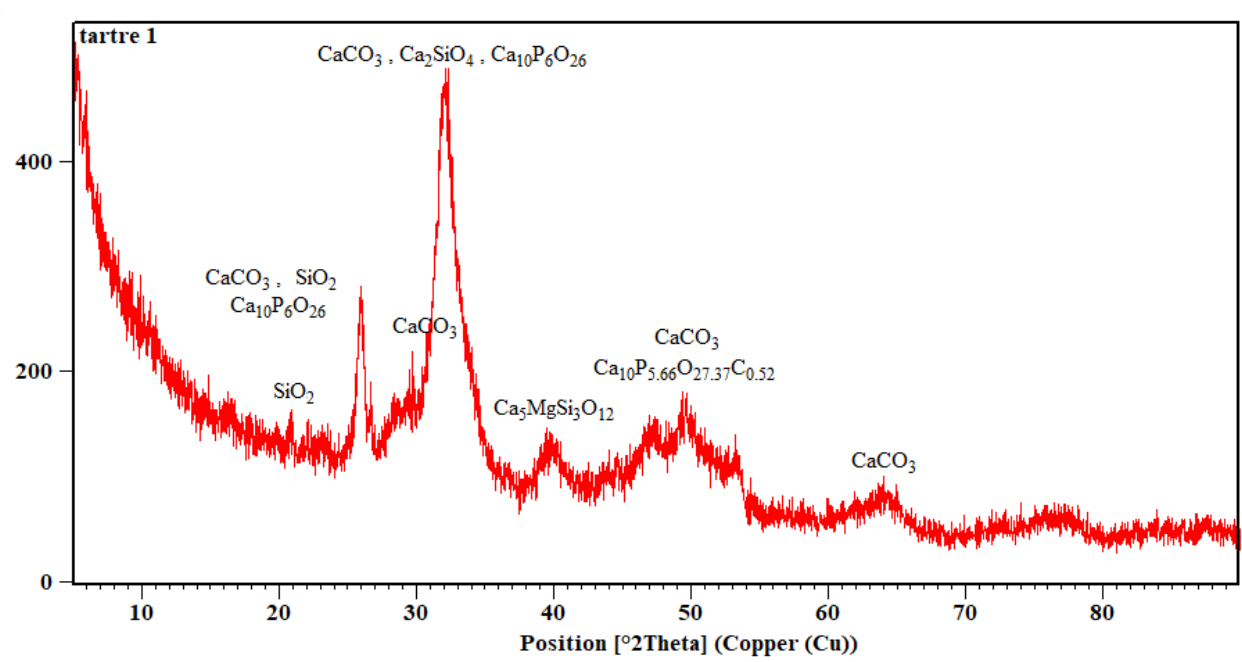

Figure 5. X-ray diffractogram of the scale taken from the sprinklers

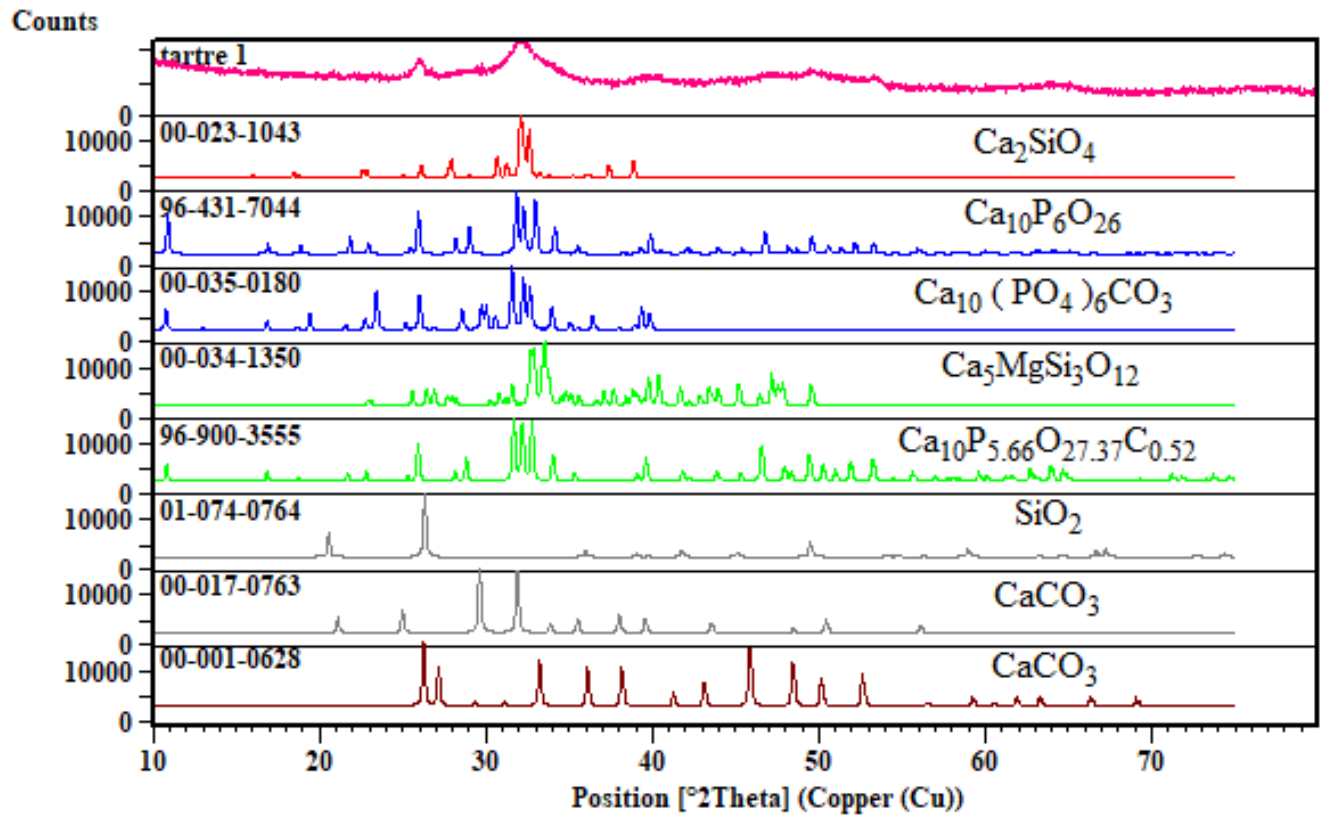

Figure 6. X-ray diffractograms of the compounds present in the scale

The broad peaks observed in Figure 5 indicate low crystallinity of the scale samples. It is seen that the samples' scale contain different minerals. The highest intensity peak refers to calcium carbonate, calcium silicate and hydroxylapatite. Many other chemical
$(0.93 \%)$, sulfuric oxide $\mathrm{SO}_{3}(0.39 \%)$, sodium oxide $\mathrm{Na}_{2} \mathrm{O}(0.32 \%)$ and iron oxide $\mathrm{Fe}_{2} \mathrm{O}_{3}(0.038 \%)$.

\subsection{X-ray diffraction analysis}

To identify and analyze the scale structure formed at the sprinklers, X-ray diffraction analysis allowed obtaining the results shown in Figures 5 and 6. 


\subsection{Thermogravimetric analysis (TGA) and differential thermal analysis (DTA)}

The thermal behavior of the scale collected on watering sprinklers of turf is followed by DTA and TGA techniques. The result of which is shown in Figure 7.

The DTA curve shows two endothermic and two exothermic peaks. The TGA curve shows four mass losses. The most significant mass loss is recorded before $450^{\circ} \mathrm{C}$. Between $0^{\circ} \mathrm{C}$ and $200^{\circ} \mathrm{C}$, the mass loss is of the order of $12 \%$ and it is due to the evaporation of water adsorbed on the crystals of scale. This is illustrated on the DTA curve by an endothermic peak centred at $95^{\circ} \mathrm{C}$. Between $200^{\circ} \mathrm{C}$ and $440^{\circ} \mathrm{C}$, the TGA curve recorded a mass loss of about $8 \%$, which can be attributed to the departure of strongly bound intercrystalline water. In the temperature that ranges from 440 to $740^{\circ} \mathrm{C}$, the DTA curve presents a marked endothermic peak at a temperature of about $725^{\circ} \mathrm{C}$ which illustrates the process of carbonate decomposition and departure of $\mathrm{CO}_{2}{ }^{8,11-13}$. At this decomposition corresponds to a mass loss of about $6 \%$. A fourth mass loss was measured between 740 and $1000^{\circ} \mathrm{C}$. It is weak in the order of $3 \%$ and may be due to decomposition of another carbonate or a morphological transformation of the compounds present in the scale ${ }^{14}$. This transformation is illustrated by an exothermic peak around $950^{\circ} \mathrm{C}^{15,16}$.

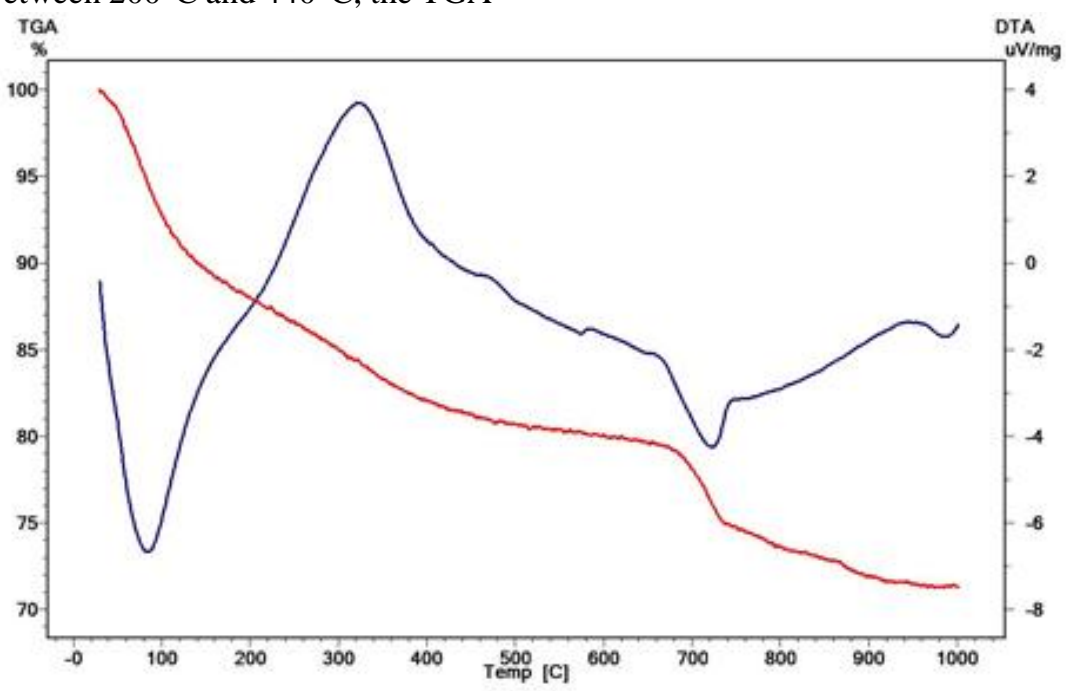

Figure 7. TGA / DTA thermograms of deposited scale in the sprinklers

3.6. Scanning Electron Microscope analysisThe scanning electron microscope (SEM) analysis of the

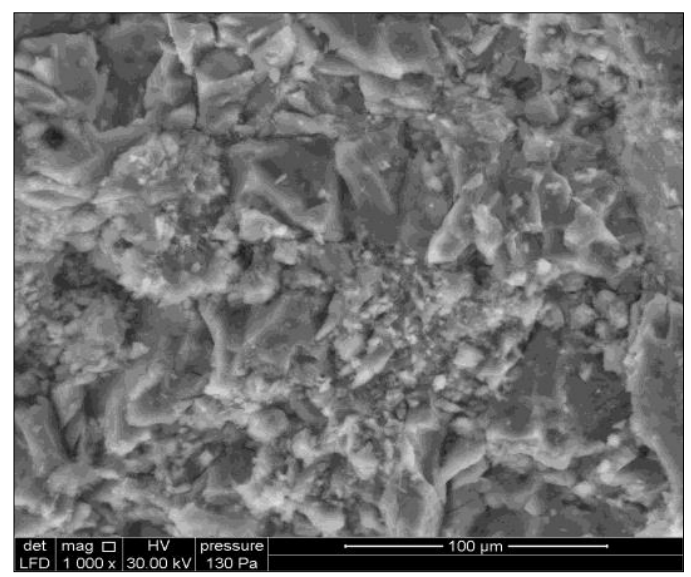

scale sample deposited in the sprinklers is given in Figure 8.

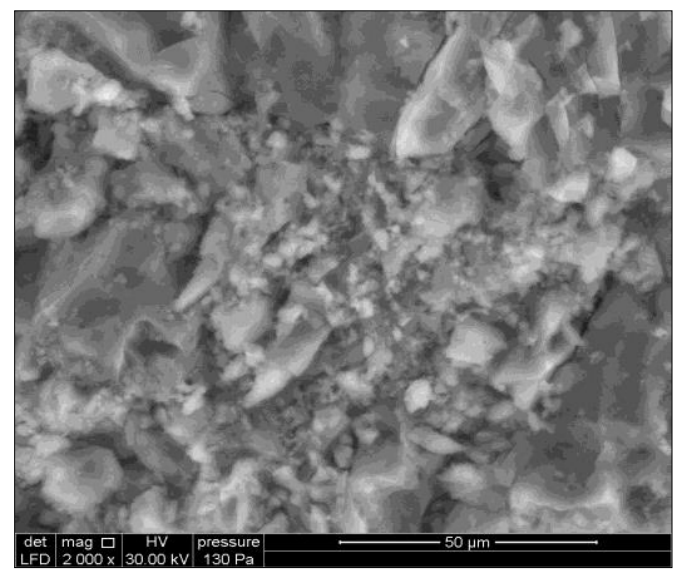

Figure 8. SEM microphotos of scale at sprinklers

It shows that the scale collected consists of crystals of various forms. Corresponding to the different compounds present in the scale and confirming the results obtained by the previous analysis techniques. It includes rhombohedral crystals of calcium carbonate of calcite-type, irregular forms of calcium silicate polymorphs and hydroxyapatite ${ }^{17}$.

\section{Conclusion}

The results of the physicochemical analysis of the treated wastewater of the Mzar treatment plant, intended for the irrigation of the turf of the "Ocean" Golf show that all factors are favorable for the formation of scale in the passageways of these waters. 
The formation of scale has caused difficulties in the irrigation system. The scale analysis collected at the level of the sprinklers by X-ray fluorescence shows that it is rich in calcium $\mathrm{Ca}(72 \%)$ and phosphorus $\mathrm{P}$ (26\%). Other elements such as $\mathrm{O}, \mathrm{Mg}, \mathrm{Fe}, \mathrm{S}$ and $\mathrm{Si}$ are present with percentages less than 1 . In the calcined product. Calcium oxide $(\mathrm{CaO})$ is the primary compound with a level of $38.92 \%$ followed by phosphorus pentoxide $\left(\mathrm{P}_{2} \mathrm{O}_{5}\right)$ with a percentage of $16.95 \%$ in weight. Other trace oxides have been detected.

X-ray diffraction scale analysis shows the presence of calcium carbonate, silica calcium, silicate hydroxyapatite, calcium and phosphate carbonate, calcium silicate and magnesium. The various analysis techniques used in this study allowed to characterize the scale deposited by the treated wastewater and show that it is a mixture of chemical compounds. Indeed, the scale deposits are the result of various actions of chemical. Physical or mechanical origin. This explains how hard it is to find adequate protection for this type of encrustations deposited by liquid effluents charged with various substances. However, this physicochemical characterization will undoubtedly make it possible to decide on the appropriate and effective treatment to put an end to scaling of the irrigation circuits by using purified water.

\section{References}

1- E. Ibariouen, La réutilisation des eaux usées épurées dans le Grand-Agadir, Régie Autonome Multi-Services d'Agadir, Les cahiers d'échange Med N ${ }^{\circ}$. XIV ${ }^{\text {ème }}$ Rencontre Internationale d'Echanges Méditerranéens au Maroc. 25/11 au 02/12/2015.

2- B. Boudinar, H. Mouhanni, M. Houari, A. Bendou, Analyses physico-chimiques du gazon irrigué par les eaux usées épurées de la station Mzar du grand Agadir- Maroc, revue internationale d'héliotechnique, 2015, 46, 1-7.

3- Programme mixte FAO/UNW-DPC/UNUINWEH. Montage Institutionnel et analyse environnementale et socioéconomique et concernant le projet de réutilisation des eaux usées épurées. Rapport global de synthèse. Mars 2012.

4- Direction des affaires intérieures, Compétitivité économique du Maroc ébauche de révision des normes de qualité des eaux usées traitées destinées à l'irrigation des cultures et a l'arrosage des espaces verts USAID. Mars 2013.

5- USAID. Réutilisation des Eaux Usées en Irrigation. United States Agency for International Development.projet de «Pérennité des Ressources en Eau du Maroc-PREM »

6- A. Kerfati, Réutilisation en irrigation des eaux usées au Maroc, DIAEA / Ministère de l'Agriculture. Agadir. 7-11 décembre 2009.
7- A. Hadfi, S. Ben Aazza, M. Belattar, S. Mohareb, A. Driouiche, "Evaluation of the irrigation water quality in Biougra circle along with highlighting the effectiveness of a scaling inhibitor", Mediterranean Journal of Chemistry, 2018.7(4), 272-285.

8- A. Kamari, F. Gharagheizi, A.Bahadori, A.H. Mohammadi, Determination of the Equilibrated Calcium Carbonate (Calcite) Scaling in Aqueous Phase Using a Reliable Approach, Journal of the Taiwan Institute of Chemical Engineers, 2014, 45, 1307-1313.

9- A. Korchef, M. Touaibi, Effect of $\mathrm{pH}$ and temperature on calcium carbonate precipitation by $\mathrm{CO}_{2}$ removal from iron-rich water, Water and Environment Journal. 2019. https://doi.org/10.1111/wej.12467

10-R. Mimouni, B. Yacoubi, R. Eddabra, Physicochemical quality of wastewater purified by infiltration-percolation: case of the plant of Ben Sergao (south-western Morocco) after ten years of running, Rev. Microbiol. Ind. San et Environn., 2011, 5(1), 101-114.

11-J. Yin, X. Kang, C. Qin, B. Feng, A. Veeraragavan, D. Saulov, Modeling of $\mathrm{CaCO}_{3}$ Decomposition under $\mathrm{CO}_{2} / \mathrm{H}_{2} \mathrm{O}$ Atmosphere in Calcium Looping Processes, Fuel Processing Technology, 2014, 125, 125-138.

12-N. Hafid, M. Belaatar, S. Ben-Aazza, A. Hadfi, M. Ezahri, A. Driouiche, Characterization of Scale Formed in Drinking Water and Hot Water Pipes in the Taliouine Downtown-Morocco, American Journal of Analytical Chemistry, 2015, 6, 677-686.

13-M.N. Freire, J.N.F. Holanda, Characterization of avian eggshell waste aiming its use in a ceramic wall tile paste, Cerâmica, 2006, 52(324), 240-244.

14-S. Serena, M.A. Sainz, A. Caballero, Singlephase silico-carnotite synthesis in the subsystem $\mathrm{Ca}_{3}\left(\mathrm{PO}_{4}\right)_{2}-\mathrm{Ca}_{2} \mathrm{SiO}_{4}$, Ceramics International, 2014, 40, 8245-8252.

15-N. Yamaguchi, Y. Masuda, Y. Yamada, H. Narusawa, C. Han-Cheol, Y. Tamaki, T. Miyazaki, Synthesis of $\mathrm{CaO}-\mathrm{SiO}_{2}$ Compounds Using Materials Extracted from Industrial Wastes, Open Journal of Inorganic Non-Metallic Materials, 2015, 5, 1-10.

16-C. Remy, B. Reynard, M. Madon, Raman spectroscopic investigations of dicalcium silicate: Polymorphs and high-temperature phase transformations, Journal of the American Ceramic Society, 1997, 80(2), 413-423.

17-Z. Gou, J. Chang, Synthesis and in vitro bioactivity of dicalcium silicate powders, Journal of the European Ceramic Society, 2004, 24, 93 99. 